\title{
Hepatocellular Carcinoma with Atrial Extension: A Case Report
}

\author{
Eduardo Dantas ${ }^{a}$ Daniel Matos $^{\mathrm{b}}$ Mariana Coelho $^{\mathrm{a}}$ Cristiana Sequeira $^{\mathrm{a}}$ \\ Cláudia Cardoso ${ }^{a}$ Ana Paula Oliveira ${ }^{a}$ \\ ${ }^{a}$ Gastroenterology Department, Hospital São Bernardo, Centro Hospitalar de Setúbal, Setúbal, Portugal; \\ ${ }^{b}$ Cardiology Department, Hospital Santa Cruz, Centro Hospitalar de Lisboa Ocidental, Lisbon, Portugal
}

\section{Keywords}

Hepatocellular carcinoma $\cdot$ Right atrial extension $\cdot$ Heart failure

\section{Abstract}

Hepatocellular carcinoma is a common malignancy usually associated with cirrhosis. Despite being a highly aggressive tumor with several cases of vascular invasion, metastatic disease to the heart is a rare condition. A 65-year-old male cirrhotic patient was admitted with dyspnea, ascites, and lower extremity edema. A transthoracic echocardiogram showed a large mass in the right atrium. Further imaging studies revealed the presence of hepatocellular carcinoma extending from the liver to the right atrium through the inferior vena cava. The cardiac mass was surgically removed to treat the symptoms of right heart failure, but unfortunately the patient died on the 30th day after surgery due to septic shock.

(C) 2020 Sociedade Portuguesa de Gastrenterologia Published by S. Karger AG, Basel

\section{Carcinoma hepatocelular com metastização auricular: relato de caso}

\section{Palavres Chave}

Carcinoma hepatocelular · Metastização auricular · Insuficiência cardíaca karger@karger.com www.karger.com/pjg

Karger

GOPEN ACCESS
(C) 2020 Sociedade Portuguesa de Gastrenterologia Published by S. Karger AG, Basel

This is an Open Access article licensed under the Creative Commons Attribution-NonCommercial-4.0 International License (CC BY-NC) (http://www.karger.com/Services/OpenAccessLicense), applicable to the online version of the article only. Usage and distribution for commercial purposes requires written permission.

\section{Resumo}

O carcinoma hepatocelular é uma neoplasia comum, maioritariamente associada à cirrose hepática. Apesar de se tratar de uma entidade clínica agressiva com predisposição à invasão vascular, a doença metastática com envolvimento cardíaco é rara. Os autores reportam o caso de um homem de 65 anos com cirrose hepática que recorreu ao serviço de urgência por um quadro clínico de dispneia, ascite e edema periférico. Foi realizado ecocardiograma transtorácico à admissão, que revelou presença de uma massa a nível da aurícula direita. A investigação clínica, laboratorial e imagiológica realizada permitiu o diagnóstico de carcinoma hepatocelular com extensão desde o fígado até à aurícula direita através da veia cava inferior. A massa intracardíaca foi removida cirurgicamente para alívio sintomático, no entanto o doente faleceu no $30^{\circ}$ dia de pós-operatório devido a choque séptico.

(0) 2020 Sociedade Portuguesa de Gastrenterologia Publicado por S. Karger AG, Basel

\section{Introduction}

Liver cancer is the fifth most common and the second most frequent cause of cancer-related death globally. Hepatocellular carcinoma (HCC) represents around $90 \%$ of all primary liver cancers [1]. Unlike HCC, cardiac tumors are a rare entity [2]; they are classified into primary and 
Fig. 1. Computed tomography of the chest (a) revealing a large mass in the RA (asterisk), and abdomen (b) presenting multiple nodular lesions on the right lobe of the liver (arrows).

Fig. 2. Cardiac magnetic resonance showing a mass extending from the liver (a) through the IVC (b), occupying the majority of the RA (asterisks).
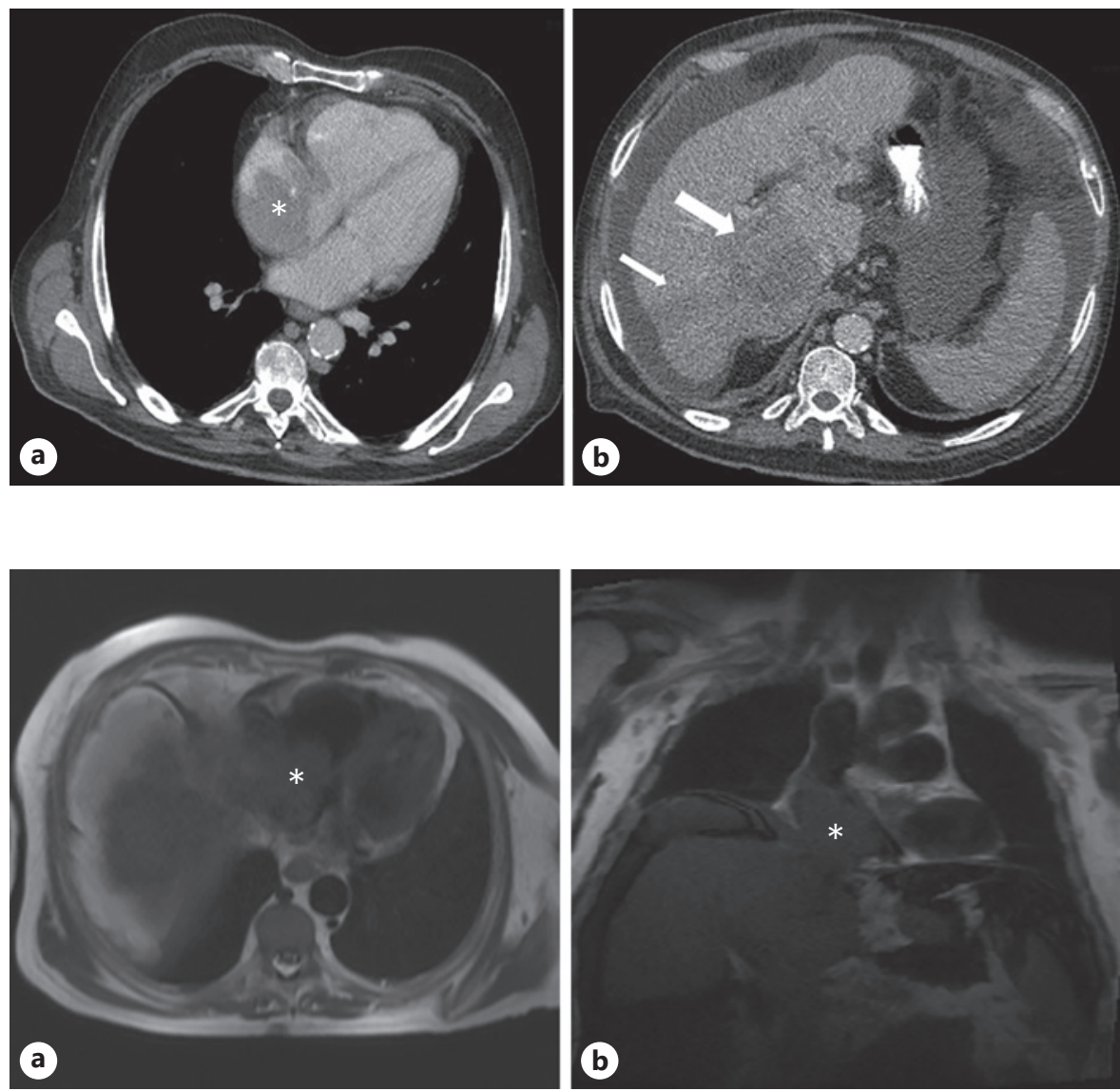

secondary. Primary cardiac tumors include all benign or malignant neoplasms arising from any heart tissue. Secondary tumors are much more common, with an incidence ranging from 2.3 to $18.3 \%$ [3]. Although any malignant tumor can metastasize to the heart, the most common are lung, breast, melanoma, pleural mesothelioma, and hematological cancers [4]; tumor invasion can occur through multiple mechanisms, including hematological, lymphatic, vascular, or direct invasion. HCC often metastasizes to bone, lungs, lymph nodes, and adrenal glands. Despite its proximity to the heart and vascular invasion potential, intracardiac metastasis are a rare manifestation of the disease. Prompt diagnosis is essential as they can cause heart failure or even sudden death.

\section{Case Presentation}

A 65-year-old male patient regularly followed in the hepatology clinic due to chronic hepatitis B (with DNA levels <2,000 IU/ $\mathrm{mL}$ ) and alcoholic cirrhosis (with previous surveillance abdominal ultrasound 8 months before showing cirrhotic liver without focal lesions), presented to the emergency department with a 1-month history of anorexia, nausea, weight loss, associated with mild exertional dyspnea, abdominal distention, and bilateral lower extremity swelling. At physical examination, the patient was hemodynamically stable (blood pressure of $110 / 70 \mathrm{~mm} \mathrm{Hg}$, heart rate 78 beats/min); cardiac examination revealed regular heart sounds without murmurs; abdomen with tense ascites; presence of bilateral lower limb edema. There was no jugular venous distension, and lungs were clear to auscultation. Initial laboratory findings showed normal hemoglobin and leucocyte count, with mild thrombocytopenia $\left(97 \times 10^{3} / \mu \mathrm{L}\right.$, normal range $\left.150-350\right)$; INR was normal (1.1, range 0.8-1.2); liver function tests had a small elevation of aspartate aminotransferase (52 U/L, normal range 5-34), a slight elevation of the bilirubin level $(1.98 \mathrm{mg} / \mathrm{dL}$, normal range $<1.2)$, and a significant elevation of $\gamma$-glutamyl transpeptidase (437 U/L, normal range 12-64) and C-reactive protein (11 mg/dL, normal range $<0.5)$. $\mathrm{N}$-terminal pro-B-type natriuretic peptide (BNP) was slightly elevated (1,415, inclusion level $>900)$. Diagnostic paracentesis excluded spontaneous bacterial peritonitis. The electrocardiogram displayed normal sinus rhythm. Urgent transthoracic echocardiogram revealed a mass with $35 \times 30 \mathrm{~mm}$ in the right atrium (RA). He was admitted for further investigation and management.

Subsequent chest, abdominal, and pelvic computed tomography revealed a large mass measuring $70 \times 30 \mathrm{~mm}$, occupying most of the RA; the abdomen presented large-volume ascites and heterogeneous liver with multiple nodular lesions on the right lobe 
suggestive of malignancy (Fig. 1); there was no evidence of pulmonary embolism or secondary lesions. The alpha-fetoprotein dosing was $14,541 \mathrm{ng} / \mathrm{mL}$ (normal range $<8$ ). A cardiac magnetic resonance confirmed previous findings, showing the cardiac mass was extending from the liver through the inferior vena cava (IVC), occupying the majority of the RA (Fig. 2). A transjugular biopsy of the cardiac mass confirmed the diagnosis of HCC. Due to the worsening of his clinical condition and the IVC occlusion, maintaining right heart failure symptoms despite optimized medical therapy, the patient underwent surgical treatment to remove the cardiac tumor. The postoperative course was complicated by septic shock caused by Klebsiella pneumoniae infection; despite treatment with broad-spectrum antibiotics, ventilatory and aminergic support, the patient died on the 30th day after surgery.

\section{Discussion}

With 854.000 new cases of liver cancer and 810.000 related deaths globally in $2015, \mathrm{HCC}$ is a common malignancy with growing incidence [5]. The recognized risk factors for HCC include alcohol-induced cirrhosis, chronic hepatitis $\mathrm{B}$ virus, and hepatitis $\mathrm{C}$ virus (HCV) infection, exposure to dietary aflatoxin, fatty liver disease, obesity, smoking, diabetes, and iron overload [6]. Regardless of its etiology, cirrhosis is a major risk factor for HCC, with approximately $1-8 \%$ of all cirrhotic patients developing HCC per year [1].

Unlike most solid cancers, the diagnosis of HCC can be established using noninvasive imaging methods without biopsy confirmation; alpha-fetoprotein and other serum biomarkers usually have a minor diagnostic role [7]. It is a clinically silent and aggressive entity, as only 30 $40 \%$ of the patients are suitable for curative treatment at diagnosis [8]. Being a highly vascular tumor with intravascular dissemination, it presents a high incidence of portal and hepatic veins thrombosis at 20-65 and 12$54 \%$, respectively $[9,10]$. In some cases, tumor thrombus can grow from the HVs through the IVC into the RA; this is a rare situation, with a reported incidence of $1-4 \%$ [11]. Most of the cardiac metastases are direct and contiguous extensions of intrahepatic tumors; isolated cardiac metastases of HCC are extremely rare [12]. A study by Jun $\mathrm{CH}$ et al. [13] identified some risk factors for RA extension in a cohort of 665 patients diagnosed with HCC (33 with RA invasion), namely a modified TNM staging classification $\geq \mathrm{IVa}$, hepatic vein invasion, concomitant $\mathrm{PV}$ and IVC invasion, and multinodular HCC. The initial investigation of choice to detect cardiac metastasis is twodimensional transthoracic echocardiography, as it is noninvasive and both pericardial involvement and intra-cavitary lesions can be detected with high sensitivity [14].
HCC with IVC and cardiac extension is associated with a higher risk for cardiopulmonary complications, with heart failure or sudden death as the cause of death in $25 \%$ of the patients [15]; other possible complications include tricuspid stenosis or insufficiency, ventricular outflow obstruction, cardiac arrhythmias, pulmonary embolism and pulmonary metastasis. Regarding symptoms, there is a wide variety of clinical manifestations, which are mainly tumor size dependent. In a study by Liu et al. [16] including 48 HCC patients with cardiac metastasis, most patients were asymptomatic (39.5\%); main symptoms were bilateral lower limb edema (37.5\%), exertional dyspnea (31.3\%), chest pain (8.3\%), syncope (2.1\%), and hypotension (2.1\%). Overall, patients may be asymptomatic or present with non-specific symptoms such as dyspnea, chest pain, presyncope or syncope, cough, fever and/or hemoptysis. Physical findings include peripheral edema, systolic murmur with diastolic rumble over the tricuspid valve, and improvement of symptoms with left lateral decubitus [17].

Advanced HCC has a poor prognosis, with a reported median survival of 4-7 months in untreated patients [18]; prognosis of HCC with RA invasion is even worse, with a life expectancy of 1-4 months [19]. Currently, there are no guidelines on the management of HCC with RA extension. Therapeutic options include palliative surgery, chemotherapy (either systemic or local), and radiation. Given that surgery to remove intracardiac mass combined with hepatectomy is the only radical treatment that may offer a chance of complete tumor removal, it has been attempted in some cases. Wang et al. [20], in a cohort of 56 patients with RA invasion by HCC, reported that prognosis following surgery was significantly better than that achieved by transarterial chemoembolization (TACE) or no treatment, suggesting that in selected patients surgical treatment may be a valid option. For those who are not candidates for surgery, both systemic and local chemotherapies have been used. Sorafenib, a multi-target tyrosine kinase inhibitor, has been shown to improve overall survival in advanced HCC [21]. TACE has also been attempted; Chern et al. [22], in a cohort of 26 patients with IVC invasion (and RA extension in 5), demonstrated that those who responded to TACE had better overall survival than non-responders.

In conclusion, cardiac metastases are an uncommon entity associated with several malignancies, including rare cases of HCC. Early diagnosis of HCC is essential to prevent cardiac presentation. Clinical suspicion should be kept in any cirrhotic patient who presents with newonset symptoms of right heart failure, as described in our case. Despite a poor prognosis, early diagnosis may allow 
prompt initiation of treatment, which should be multidisciplinary and individualized, aiming to improve quality of life.

\section{Statement of Ethics}

This study did not require informed consent or review approval by the appropriate ethics committee.

\section{Conflict of Interest Statement}

The authors declare that they have no conflicts of interest to disclose.

\section{Funding Sources}

The authors declare that they did not receive any funding for this work.

\section{Author Contributions}

All authors contributed to the study conception and design. Material preparation, data collection, and the first draft of the manuscript was performed by Eduardo Dantas. All authors read and approved the final manuscript.

\section{References}

1 Galle PR, Forner A, Llovet JM, Mazzaferro V, Piscaglia F, Raoul JL, et al.; European Association for the Study of the Liver. Electronic address: easloffice@easloffice.eu; European Association for the Study of the Liver. EASL Clinical Practice Guidelines: management of hepatocellular carcinoma. J Hepatol. $2018 \mathrm{Jul}$; 69(1):182-236.

2 YusufSW, Bathina JD, Qureshi S, Kaynak HE, Banchs J, Trent JC, et al. Cardiac tumors in a tertiary care cancer hospital: clinical features, echocardiographic findings, treatment and outcomes. Heart Int. 2012 Feb;7(1):e4.

3 Bussani R, De-Giorgio F, Abbate A, Silvestri F. Cardiac metastases. J Clin Pathol. 2007 Jan; 60(1):27-34.

4 Barrett M, Viglianti BL, Hanson CA, Schildhouse RJ. A Case of Right Atrial Obliteration Caused by Intracardiac Extension of Hepatocellular Carcinoma. Case Rep Oncol. 2017 Jan;10(1):8-14.

5 Akinyemiju T, Abera S, Ahmed M, Alam N, Alemayohu MA, Allen C, et al.; Global Burden of Disease Liver Cancer Collaboration. The Burden of Primary Liver Cancer and Underlying Etiologies From 1990 to 2015 at the Global, Regional, and National Level: Results From the Global Burden of Disease Study 2015. JAMA Oncol. 2017 Dec;3(12):1683-91.

6 Wong MC, Jiang JY, Goggins WB, Liang M, Fang Y, Fung FD, et al. International incidence and mortality trends of liver cancer: a global profile. Sci Rep. 2017 Mar;7:45846.

7 Marrero JA, Kulik LM, Sirlin CB, Zhu AX, Finn RS, Abecassis MM, et al. Diagnosis, Staging, and Management of Hepatocellular Carcinoma: 2018 Practice Guidance by the American Association for the Study of Liver Diseases. Hepatology. 2018 Aug;68(2):723-50.
8 Kamal MW, Farshidpour M, Long AW, Farooqui S, Cunningham SC. Hepatocellular carcinoma with intra-atrial extension responding to transarterial chemoembolization via the right hepatic and right inferior phrenic arteries. Gastrointest Cancer Res. 2014 May;7(3-4):111-6.

9 Connolly GC, Chen R, Hyrien O, Mantry P, Bozorgzadeh A, Abt P, et al. Incidence, risk factors and consequences of portal vein and systemic thromboses in hepatocellular carcinoma. Thromb Res. 2008;122(3):299-306.

10 Sneag DB, Krajewski K, Giardino A, O’Regan $\mathrm{KN}$, Shinagare AB, Jagannathan JP, et al. Extrahepatic Spread of Hepatocellular Carcinoma: Spectrum of Imaging Findings. AJR Am J Roentgenol. 2011 Oct;197(4):W658-64.

11 Vallakati A, Chandra PA, Frankel R, Shani J. Intra-atrial tumor thrombi secondary to hepatocellular carcinoma responding to chemotherapy. N Am J Med Sci. 2011 Sep;3(9):4357.

12 Kawakami M, Koda M, Mandai M, Hosho K, Murawaki Y, Oda W, et al. Isolated metastases of hepatocellular carcinoma in the right atrium: case report and review of the literature. Oncol Lett. 2013 May;5(5):1505-8.

13 Jun CH, Sim DW, Kim SH, Hong HJ, Chung MW, Cho SB, et al. Risk factors for patients with stage IVB hepatocellular carcinoma and extension into the heart: prognostic and therapeutic implications. Yonsei Med J. 2014 Mar; 55(2):379-86

14 Muneer AR, Biji S, Suman OS, Peter KJ, Vijayaraghavan G, Leena D. Transvascular Growth of Hepatocellular Carcinoma. JCR. 2017;7:136-8.

15 Sung AD, Cheng S, Moslehi J, Scully EP, Prior JM, Loscalzo J. Hepatocellular carcinoma with intracavitary cardiac involvement: a case report and review of the literature. Am J Cardiol. 2008 Sep;102(5):643-5.
16 Liu YC, Ho YL, Huang GT, Chen DS, Sheu JC Chen $\mathrm{CH}$. Clinical manifestations and survival of patients with hepatocellular carcinoma and cardiac metastasis. J Gastroenterol Hepatol. 2010 Jan;25(1):150-5.

17 Dedeilias P, Nenekidis I, Koukis I, Anagnostacou V, Paparizou N, Zompolos S, et al. Acute heart failure caused by a giant hepatocellular metastatic tumor of the right atrium. J Cardiothorac Surg. 2011 Aug;6:102.

18 Natsuizaka M, Omura T, Akaike T, Kuwata Y, Yamazaki K, Sato T, et al. Clinical features of hepatocellular carcinoma with extrahepatic metastases. J Gastroenterol Hepatol. 2005 Nov;20(11):1781-7.

19 Chang JY, Ka WS, Chao TY, Liu TW, Chuang TR, Chen LT. Hepatocellular carcinoma with intra-atrial tumor thrombi. A report of three cases responsive to thalidomide treatment and literature review. Oncology. 2004;67(34):320-6.

20 Wang Y, Yuan L, Ge RL, Sun Y, Wei G. Survival benefit of surgical treatment for hepatocellular carcinoma with inferior vena cava/ right atrium tumor thrombus: results of a retrospective cohort study. Ann Surg Oncol. 2013 Mar;20(3):914-22.

21 Peng S, Zhao Y, Xu F, Jia C, Xu Y, Dai C. An updated meta-analysis of randomized controlled trials assessing the effect of sorafenib in advanced hepatocellular carcinoma. PLoS One. 2014 Dec;9(12):e112530.

22 Chern MC, Chuang VP, Cheng T, Lin ZH, Lin YM. Transcatheter arterial chemoembolization for advanced hepatocellular carcinoma with inferior vena cava and right atrial tumors. Cardiovasc Intervent Radiol. 2008 JulAug;31(4):735-44. 